\title{
Jan Herman, Le récit génétique au XVIII siècle
}

\section{Regina Bochenek-Franczakowa}

\section{OpenEdition \\ Journals}

\section{Édition électronique}

URL : http://journals.openedition.org/studifrancesi/6285

DOI : 10.4000/studifrancesi.6285

ISSN : 2427-5856

\section{Éditeur}

Rosenberg \& Sellier

\section{Édition imprimée}

Date de publication : 1 novembre 2010

Pagination : 551

ISSN : 0039-2944

\section{Référence électronique}

Regina Bochenek-Franczakowa, "Jan Herman, Le récit génétique au xvII" siècle », Studi Francesi [En ligne], 162 (LIV | III) | 2010, mis en ligne le 30 novembre 2015, consulté le 09 janvier 2021. URL : http:// journals.openedition.org/studifrancesi/6285; DOI : https://doi.org/10.4000/studifrancesi.6285

Ce document a été généré automatiquement le 9 janvier 2021.

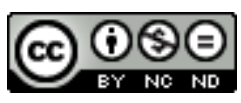

Studi Francesi è distribuita con Licenza Creative Commons Attribuzione - Non commerciale - Non opere derivate 4.0 Internazionale. 


\section{Jan Herman, Le récit génétique au XVIII siècle}

Regina Bochenek-Franczakowa 


\section{RÉFÉRENCE}

JAN HERMAN, Le récit génétique au XVIII ${ }^{e}$ siècle, Oxford, Voltaire Foundation, 2009 («SVEC» 2009:11), pp. 259.

Dans son ouvrage, Jan Herman mène une enquête sur le roman du XVIII ${ }^{\mathrm{e}}$ siècle ayant à démontrer le bienfondé de l'affirmation de T. Todorov sur la mimésis textuelle de toute œuvre littéraire. Le récit génétique est ici défini et compris comme «l'histoire du devenir-livre, lisible en filigrane, d'un matériau textuel» (p. 45). Le terme-clé qui fonde l'ensemble d'outils méthodologiques est le filigrane textuel, soit «l'inscription dans le texte de ses états antérieurs» (p. 36). L'auteur considère les relais narratifs, le péritexte et l'incipit comme les lieux stratégiques du roman qui laissent transpercer «les divers prototextes accumulés dans la mémoire du texte» (p. 37). La mimésis textuelle, concept rarement appliqué au roman du $\mathrm{XVIII}^{\mathrm{e}}$ siècle, se trouve ici magistralement développé dans sa dimension tant théorique qu'herméneutique. D'un côté, Jan Herman propose une conception originale de l'illusion romanesque basée sur l'autonomisation de l'univers romanesque "grâce à l'absorption de l'acte producteur même», ce qui entraîne la subordination de la narration à l'histoire (p. 48). D'un autre côté, l'enquête menée avec finesse et brio sur un corpus de romans choisis avec soin, permet à l'auteur de vérifier et démontrer la justesse de ses théories. Parmi les œuvres examinées, l'on trouve trois romans de Prévost, La Vie de Marianne de Marivaux, Les Liaisons dangereuses de Laclos, Le Manuscrit trouvé à Saragosse de Potocki, et bien d'autres. La méthode, qui unit l'approche structuraliste avec certains acquis de la psychanalyse littéraire (la métaphore parentale de l'enfant trouvé, qui fonde le «roman familial»), crée ici un outil d'analyse original et efficace, grâce auquel Jan Herman a renouvelé en profondeur l'interprétation du roman des Lumières. 